\title{
Development of Physics Laboratory Manual: Characteristic of Resistors Circuit
}

\author{
Ricky Ramdani ${ }^{1}$, Eka Murdani ${ }^{2}$, Intan Kusumawati ${ }^{3}$, Haewoon Park ${ }^{4}$ \\ College of Teacher Training and Education (STKIP) Singkawang, Singkawang, Indonesia ${ }^{1,2,3}$, \\ Daegu University, Gyeongsan, South Korea ${ }^{4}$ \\ rickyramdani0310@yahoo.com ${ }^{1}$, ekamurdani@gmail.com², intankusumawati10@gmail.com³, \\ betmanbear@naver.com ${ }^{4}$
}

Received: October $9^{\text {st }}, 2018$. Revised: February $25^{\text {th }}, 2019$. Accepted: February $27^{\text {th }}, 2019$

\section{Keywords :}

Physics Laboratory Manual;

Resistor Circuit;

Electromagnetics

\begin{abstract}
This study aimed to produce a physics laboratory manual characteristic of a single, series, parallel and seriesparallel series of resistors; found out the quality of the physics laboratory manual characteristics of a single, series, parallel and series-parallel series of resistors. This research is a research development. Data collection in this study used suggestion and input sheets, quality assessment sheets for laboratory manual and student response sheets. Laboratory manual quality data obtained from three assessors, student response data for the limited trial I involving six students, and limited trial II involving 28 students. The physics laboratory manual characteristics of a single, series, parallel and series-parallel circuit of resistors have been produced with the criteria of "very eligible" based on final validation by media expert with a percentage of $97 \%$ and declared "very eligible" based on final validation by material expert with a percentage amounting to $83.90 \%$ and stated to be "very eligible" based on the final assessment by lecturer of electromagnetics courses with a percentage of $80 \%$. This physics laboratory manual received a "very good" response from students with a percentage reaching $82 \%$ in limited trial I and received a "very good" response with a percentage of $82.60 \%$ in limited trial.
\end{abstract}

\section{INTRODUCTION}

Education is a conscious effort to grow the potential of human resources through learning activities. National Education System Law No. 20 of 2003 states that the aim of national education is to educate the lives of the nation and develop Indonesian people as a whole, that is, people who fear God Almighty and have noble character, possess knowledge and skills, physical and spiritual health, a strong and independent personality and social responsibility and nationality [1]. The success rate of achieving educational goals depends a lot on how the learning process is experienced by students as students [2]. Along with the rapid development of science and technology, the College of Teacher 
Training and Education (STKIP) Singkawang is one of the institutions that educate teachers who constantly strive to produce future teachers who are knowledgeable about science and technology. STKIP Singkawang applies a variety of learning models that can improve students' understanding and learning achievement such as applying multimedia-based lectures or Information and Communication Technology (ICT). Specifically, in the Physics Education Study Program, there is also a good practice with modeling, animation, simulation or practicum directly in the laboratory.

Physics is the knowledge gained through seeing, observing, reducing the phenomenon of natural phenomena that occur in surrounding life [3]. Physics is seen as a process and product at the same time, so that in learning it must consider effective and efficient strategies or methods of learning, one of which is through practicum activities. Practicum-based learning is a good alternative learning for students to develop skills, the ability to think (hands-on and minds-on) because students are required to be active in solving problems, thinking critically and creatively in analyzing and applying concepts, and principles to be more meaningful [4].

Physics learning must be based on observation activities, not just theory. Physics learning with practicum is very rarely done due to many things such as lack of inventory of practical tools, practice rooms, practice modules, and incomprehension to pour teaching materials into practical materials [5][6]. With practicum, physics learning is based on the effort to involve students as learners with natural phenomena being studied, more familiar with facts and a more complete understanding, thus impacting on increasing understanding of physics concepts [7][8]. Therefore, there is a need for modeling or practicum activities in physics learning.

Another term practicum-based learning is Research-Based Learning (RBL). Practicum-based learning makes learning more directed to experimental learning based on concrete experience, discussion with friends, which will then obtain new ideas and concepts [4]. Practicum is an inseparable part of science learning which aims to provide opportunities for students to test hypotheses or observations of real objects related to concepts or theories [9]. Based on the description, it can be concluded that practicum-based learning is more directed to experimental learning which can be an alternative learning in developing students' critical thinking skills and abilities.

The physics laboratory manual that will be designed by researchers is a practicum characteristic of a single, series, parallel, and series-parallel resistors circuit. Resistor is one of the electronic components that play an important role to inhibit the current strength in electronic circuits. Resistor characteristics in some circuits are interested in being studied as they function in the circuit. Based on this background, the research will be carried out with the title "Development of Physics Laboratory Manual: Characteristics of Single, Series, Parallel, and Series-Parallel Resistors Circuit". This research is expected to be applied in the STKIP Singkawang physics laboratory as an alternative learning resource in the form of laboratory manuals, especially in electromagnetics courses.

\section{METHOD}

The study design that used is a research and development which is modified from Sugiyono [10]. Development research procedures are problem orientation, data collection, product design, product validation, product revision, the limited trial I, product revision, product validation, product revision, the limited trial II, product revision, and final product. The study was conducted at the STKIP Singkawang Physics Laboratory with students of the Physics Education program and lecturer of electromagnetics as research subjects. The variables measured in this study were the eligibility of physics laboratory manual and student responses to the physics laboratory manual characteristics of a single, parallel, and series-parallel resistors circuit. The eligibility of the physics laboratory manual is measured based on the results of the assessment of material expert and media expert, as well as lecturer of 
electromagnetics courses through questionnaires. Student responses are measured based on the results of student response questionnaires to the physics laboratory manual. The questionnaire that used was a modification of the questionnaire compiled by Crisnandari [11] with answers to statements on the questionnaire using a Likert scale. Data were analyzed descriptively by percentage.

\section{RESULTS AND DISCUSSIONS}

Resistors are electronic components that are designed to have two poles which can later be used to hold an electric current when the voltage is applied between the two poles. Resistors are usually widely used as part of electronic circuits. This component tends to be used compared to other components. Resistors are components made of insulating materials which contain certain values in accordance with the resistance value $(R)$ desired. Based on Ohm's law, the voltage value $(V)$ of the resistance is directly proportional to the current $(I)$ flowing. Mathematically Ohm's law is expressed in the form of equation (1).

$$
V=I \cdot R
$$

The shape of the resistors currently varies. Resistors that most common and often found on the market are elliptical and there are several color circles on the body of the resistor. The resistance value varies from below $1 \Omega$ to above $10^{7} \Omega(10 \mathrm{M} \Omega$ ). The resistor value is expressed in circular color codes on the component. The number of codes is generally three. But for a more precise resistor, there are four color codes. The value of the obstacle is determined by the first three color codes. The fourth color code is called tolerance which determines the accuracy of the value of obstacles [12].

The main characteristic of resistors is their resistance and electrical power that can be delivered. Resistors can also be integrated into hybrid circuits and circuit boards, and can even use integrated circuits. The size and location of the resistor foot depend on the design of its circuit, the resistor power produced must also be in accordance with the need for the circuit not to be burned [12].

An electrical circuit is a form of a circuit arranged by several components (elements) of electricity that are connected to each other. The electrical component can be a resistor (as an obstacle), a voltage source (a power supply), a lamp, a switch, a transistor, and other electrical components. In an electrical circuit, the things that become the center of attention are voltage and current strength at various points along the circuit. In circuits with constant voltage and current (does not change with time), the current is limited by its resistance [13].

\section{Products of Physics Laboratory Manual}

In this study, a physics laboratory manual has been developed that includes material characteristics of single, series, parallel, and parallel-series resistors circuit. Physics laboratory manual is made in A4 paper size $(21 \mathrm{~cm} \times 29.7 \mathrm{~cm})$. This book also has pictures that support practicum material, so it helps facilitate students in carrying out practical instructions according to procedures. The development laboratory manual has several components as follows: (1) one front cover page containing the practicum title, the author's name, the origin of the study program, the agency logo and equipped with resistor images as a front cover decoration; (2) an introductory page containing the introduction from the author; (3) one page of the rules of physics practicum that contains rules that must be obeyed by the practitioner during the practicum; (4) one page for the use of the practicum book which contains steps that must be practiced to learn the laboratory manual; (5) one page of table of contents contains a list of pages to make it easier to find the main page of material; (6) two pages of measurement uncertainty theory contain measurement uncertainty theories; (7) the page number of practicum 1 contains a practicum with the title of a single resistor; (8) nine pages of practicum 2 contain a practicum with the title characteristic of the resistors circuit; (9) one systematic page of writing a practicum report contains steps for writing the final report of the practicum; (10) one page 
bibliography contains material/library sources.

Physics laboratory manual: characteristics of single, series, parallel and series-parallel resistors have practicum pages consisting of the following parts: (1) practicum title; (2) the purpose of the experiment contains the objectives to be achieved in the practicum; (3) a literature review containing material related to the practicum; (4) tools and materials containing the tools and materials used when conducting the practicum; (5) practical steps containing instructions or ways when conducting the practicum; (6) observation table is a table used to write observations; (7) preliminary assignment is a task that must be done by the practitioner and submitted before conducting the practicum; (8) the final project is a task that must be done by the practitioner after the practicum before leaving the laboratory and published in the practicum report.

Products in the form of a physics laboratory manual: characteristic of a single, series, parallel, and series-parallel resistors circuit have gone through the eligibility assessment stage by material expert, media expert, and lecturer of electromagnetics courses. The results of assessment I accompanied by suggestions and input from experts became the basis for the revision of the physics laboratory manual and then tested in limited trial I. The results of the limited trial I was then revised and was done assessment II by experts. The results of assessment II accompanied by suggestions and input from experts became the basis for the revision of the physics laboratory manual which will later be piloted in a limited trial II. The revised results from the results of the limited trial II are the final product in the form of a physics laboratory manual: characteristic of a single, series, parallel, and series-parallel resistors circuit that are ready to be used as laboratory manual for students of STKIP Singkawang Physics Education study program in physics laboratories, especially lecture electromagnetics.

\section{Eligibility Assessment of the Physics Laboratory Manual}

The eligibility assessment of a physics laboratory manual: characteristics of single, series, parallel and series-parallel resistors circuit is carried out in order to obtain an assessment from experts in the development of this laboratory manual. In addition, the objective of the eligibility assessment of the physics laboratory manual is to obtain constructive input so that the developed physics laboratory manual is better. The following is an assessment by experts.

Material Expert Assessment: Criteria for the percentage score of the assessment of a physics laboratory manual: characteristics of single, series, parallel and series-parallel resistors circuit by material expert carried out based on the National Education Standards Agency (BSNP) shown in Table 1. Results recapitulation of the material expert assessment of the physics laboratory manual: characteristics of single, series, parallel, and series-parallel resistors are shown in Table 2.

Table 1. Criteria for Percentage of Assessment Scores Based on BSNP [14]

\begin{tabular}{cc}
\hline Score & Criteria \\
\hline $81.25 \%<$ score $\leq 100 \%$ & Very Eligible \\
$62.50 \%<$ score $\leq 81.25 \%$ & Eligible \\
$43.75 \%<$ score $\leq 62.50 \%$ & Less Eligible \\
$25 \%<$ score $\leq 43.75 \%$ & Ineligible \\
\hline
\end{tabular}

Table 2. Results Recapitulation of The Material Expert Assessment [11]

\begin{tabular}{ccc}
\hline Aspect & Percentage & Category \\
\hline Material coverage & $75 \%$ & Eligible \\
Material accuracy & $83 \%$ & Very Eligible \\
Material update & $75 \%$ & Eligible \\
Encouraging curiosity & $87.5 \%$ & Very Eligible \\
Layout & $87.5 \%$ & Very Eligible \\
Implementation of practicum & $92 \%$ & Very Eligible \\
\hline Average & $\mathbf{8 3 . 9 \%}$ & Very Eligible \\
\hline
\end{tabular}


The results of the material expert assessment showed that the average percentage was $83.9 \%$. Thus, the physics laboratory manual is categorized as "Very Eligible" according to the material expert.

Media Expert Assessment: Criteria for the percentage score of the assessment of the physics laboratory manual: characteristics of single, series, parallel and series-parallel resistors circuit by media expert carried out based on Table 1. Results recapitulation of the media expert assessment of the physics laboratory manual: characteristics of single, series, parallel, and series-parallel resistors are shown in Table 3.

The results of the media expert assessment showed that the average percentage was $97.00 \%$. Thus, the physics laboratory manual is categorized as "Very Eligible" according to media expert.

Table 3. Results Recapitulation of The Media Expert Assessment [11]

\begin{tabular}{ccc}
\hline Aspect Assessment & Percentage & Criteria \\
\hline General view & $90 \%$ & Very Eligible \\
Layout & $95 \%$ & Very Eligible \\
Language/legibility & $100 \%$ & Very Eligible \\
\hline Average Percentage & $\mathbf{9 7 \%}$ & Very Eligible \\
\hline
\end{tabular}

Assessment of the Lecturer: Criteria for the percentage score of the assessment of the physics laboratory manual: characteristics of single, series, parallel and series-parallel resistors circuit by the lecturer of the electromagnetics course is based on Table 1. Results recapitulation of the lecturer assessment of the physics laboratory manual: characteristics of single, series, parallel, and seriesparallel resistors are shown in Table 4.

Table 4. Results Recapitulation of The Lecturer Assessment [11]

\begin{tabular}{ccc}
\hline AspectAssessment & Percentage & Criteria \\
\hline Material coverage & $75 \%$ & Eligible \\
Material accuracy & $100 \%$ & Very Eligible \\
Encouraging curiosity & $75 \%$ & Eligible \\
Presentation & $75 \%$ & Eligible \\
General view & $79.10 \%$ & Eligible \\
Languages/legibility & $75 \%$ & Eligible \\
Implementation of practicum & $81.25 \%$ & Eligible \\
\hline Percentage & $\mathbf{8 0 \%}$ & Eligible
\end{tabular}

The results of the lecturer assessment indicated that the average percentage was $80 \%$. Thus, the physics laboratory manual is categorized as " Eligible" according to the lecturer. Eligibility of physics laboratory manual: characteristics of single, series, parallel, and series-parallel resistors circuit based on the assessment of material expert, media expert, and lecturer displayed by the diagram in Fig. 1.

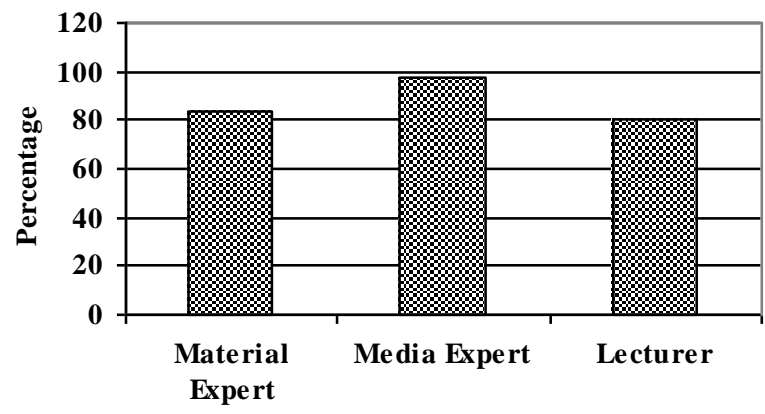

Fig 1. Diagram of Assessment Results of Material Expert, Media Expert, and Lecturer 
Based on Fig 1, the eligibility of the physics laboratory manual: characteristics of single, series, parallel, and series-parallel resistors circuit according to the material expert is very eligible with a percentage of $83.90 \%$; according to media expert have a very eligible category with a percentage of $97.00 \%$; whereas according to lecturer the electromagnetics courses are in the eligible category with a percentage of $80.00 \%$. This result is also in line with the research of Sumarli et al [6] that the physics laboratory manual: testing the type of commercial conductor wire produced has a very eligible category both in terms of material, media, and its application by lecturer of electromagnetics courses.

\section{Student Response to the Physics Laboratory Manual}

To find out the students response to the physics laboratory manual: characteristics of single, series, parallel, and series-parallel resistors circuit that have been developed, limited trial I and II were carried out. The limited trial I was conducted for six students of the STKIP Singkawang Physics Education study program consisting of three fourth semester students and three sixth semester students. While the limited trial II was conducted for all students of the Physics Education STKIP Singkawang study program, both in the second, fourth, and sixth semester, totaling 28 students. Student responses to the physics laboratory manual: characteristics of single, series, parallel, and series-parallel resistors circuits are categorized as "Very Good" if $(75 \%<$ score $\leq 100 \%)$; "Good" if $(50 \%<$ score $\leq 75 \%)$; "Less Good" if $(25 \%<$ score $\leq 50 \%)$; and "Not Good" if the score is $\leq 25 \%$ [14]. The recapitulation of student responses to the physics laboratory manual: characteristics of single, series, parallel, and series-parallel resistors circuits in the limited trial I shown in Table 5 and limited trial II are shown in Table 6.

Table 5. Results Recapitulation of Students Response on Limited Trial I [11]

\begin{tabular}{ccc}
\hline Aspect & Percentage & Criteria \\
\hline Spur curiosity & $85 \%$ & Very Good \\
Layout & $80 \%$ & Good \\
General view & $84 \%$ & Very Good \\
Language/legibility & $84 \%$ & Very good \\
Implementation of practicum & $81 \%$ & Good \\
\hline Percentage & $\mathbf{8 2 \%}$ & Very Good \\
\hline
\end{tabular}

Table 6. Results Recapitulation of Students Response on Limited Trial II [11]

\begin{tabular}{ccc}
\hline Aspect & Percentage & Criteria \\
\hline Encourage curiosity & $84.30 \%$ & Very Good \\
Layout & $79.30 \%$ & Good \\
General view & $81.90 \%$ & Good \\
Language/legibility & $76.70 \%$ & Good \\
Implementation of practicum & $79 \%$ & Good \\
\hline Percentage & $\mathbf{8 2 . 6 0 \%}$ & Very Good \\
\hline
\end{tabular}

Stem diagram resulting from student responses to the physics laboratory manual: characteristics of single, series, parallel, and series-parallel resistors circuits in limited trial I and limited trial II are shown in Fig 2.

Based on Fig 2, the students response on the physics laboratory manual: characteristics of single, series, parallel, and series-parallel resistors circuits in the limited trial I obtained an average percentage of $82 \%$ in the very good category and experienced an increase in the limited trial II obtained by an average percentage of $82.60 \%$ with very good category. This result is also not much different from the study of Sumarli et al [6] that the physics laboratory manual testing the type of commercial conductor wire produced had a very good response from students. This means that the physics laboratory manual produced can stimulate the curiosity and activity of students in attending lectures so that it is expected to improve the understanding of students' concepts. 


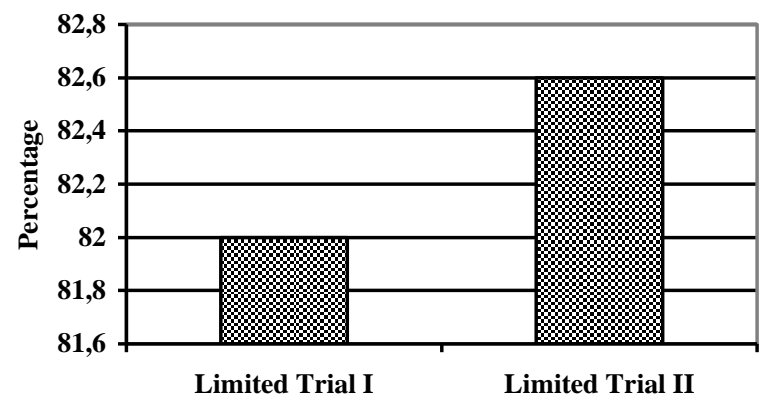

Fig 2. Results Diagram of Students Response on Limited Trial I and Limited Trial II

\section{CONCLUSION}

Based on the results of the study it was concluded: (1) A laboratory manual has been produced which has a cover page specification, introductory page, physics practicum order page, physics laboratory manual page, measurement uncertainty theory page, table of contents, practicum worksheet page, systematics of report, and bibliography. (2) Physics laboratory manual for single, series, parallel and series-parallel resistors circuits included in the criteria of "Very Eligible" based on final validation by media expert with a percentage of $97 \%$ and declared "Very Eligible" based on final validation by material expert with a percentage of $83.90 \%$ and declared "Eligible" based on the final assessment by a lecturer of Electromagnetics with a percentage of $80 \%$ and getting a "Very Good" response from students with a percentage reaching $82 \%$ in limited trial I and getting a response "Very Good" with a percentage reaching $82.60 \%$ in a limited trial II. Limitations the product trials carried out were only limited tests so that eligible categories based on the results of the research were only suitable for use in STKIP Singkawang, to be used in other campuses must be tested on a wide scale or public test. This research is only at the stage of testing the eligibility of the physics laboratory manual: characteristic of a single, series, parallel, and series-parallel resistors circuits up not to test the effectiveness of the laboratory manual after the students use it and not measure the influence of the laboratory manual on student learning outcomes.

\section{REFERENCES}

[1] Pemerintah Republik Indonesia. (2003). Undang-Undang Republik Indonesia No. 20 Tahun 2003 tentang Sistem Pendidikan Nasional. Jakarta.

[2] Wardani, A. I. K. (2013). Pengaruh Metode Eksperimen dengan Media Modul Berbasis Karakter terhadap Hasil Belajar Siswa SMP Negeri 3 Godong. Skripsi. IKIP PGRI Semarang. Unpublished.

[3] Kholifudin, M. Y. (2014). Profil Pembelajaran Fisika Berbasis Riset Sederhana melalui Praktikum pada Siswa Kelas XII IPA4 SMA Negeri 2 Kebumen. Prosiding Pertemuan Ilmiah XXVIII HFI Jateng \& DIY. pp. 149-152.

[4] Ariyati, E. (2010). Pembelajaran Berbasis Praktikum untuk Meningkatkan Kemampuan Berpikir Kritis Mahasiswa. Jurnal Matematika dan IPA, 1(2): 2-5.

[5] Rosdianto, H., \& Toifur, M. (2017). Implementasi Teori Distribusi Probabilitas Gaussian Pada Kualitas Rangkaian Penyearah Gelombang Penuh. SPEKTRA: Jurnal Fisika dan Aplikasinya, 2(1): 83-90.

[6] Sumarli, Murdani, E., \& Wijaya, A. K. (2017). Pengembangan Buku Petunjuk Praktikum Fisika: Pengujian Jenis Kawat Konduktor Komersial. JIPF (Jurnal Ilmu Pendidikan Fisika), 2(2): 30-34. 
[7] Sumarli, \& Murdani, E. (2015). Model Pembelajaran Kolaboratif dengan Tutor Sebaya pada Pokok Bahasan Rangkaian Seri Paralel Hambatan Listrik. Jurnal Riset dan Kajian Pendidikan Fisika, 1(2): 42-46.

[8] Rosdianto, H. (2017). Penentuan Percepatan Gravitasi Pada Percobaan Gerak Jatuh Bebas Dengan Memanfaatkan Rangkaian Relai. SPEKTRA: Jurnal Fisika dan Aplikasinya, 2(2): 107112.

[9] Pannen, P. (1996). Strategi Kognitif dalam mengajar di perguruan Tinggi Program Applied Approach. Jakarta: Pusat Antar Universitas Dikti.

[10] Sugiyono. (2014). Metode Penelitian Pendidikan Kuantitatif, Kualitatif, dan R\&D. Bandung: Alfabeta.

[11] Crisnandari, R. (2014). Pengembangan Buku Petunjuk Praktikum Berbasis POE (Predict, Observe, Explain) Materi Listrik Dinamis Kelas X Semester II di MAN Maguwoharjo. Skripsi. Yogyakarta: Program Studi Pendidikan Fisika, Fakultas Sains dan Teknologi, UIN Sunan Kalijaga. Unpublished.

[12] Abdullah, M. (2006). Diktat Kuliah Fisika Dasar II Tahap Persiapan Bersama ITB. FMIPA, Bandung: Institut Teknologi Bandung.

[13] Tarigan, L. B. (2014). Perancangan Aplikasi Penghitungan Kuat Arus, Hambatan, dan Tegangan dalam Rangkaian Listrik Tertutup Dengan Menggunakan Metode Heuristik. Majalah Ilmiah Informasi dan Teknologi Ilmiah, 2(2).

[14] Muhafid, E. A. (2013). Pengembangan Modul IPA Terpadu Berpendekatan Keterampilan Proses pada Tema Bunyi di SMP Kelas VIII. Skripsi. Semarang: Program Studi Pendidikan IPA, Fakultas Matematika dan Ilmu Pengetahuan Alam, UNNES. Unpublished. 